\title{
Provincial Funding of Postsecondary Education Under The Established Programs Financing*
}

\author{
TERRY YUK SHING WU**
}

\begin{abstract}
This study reviews the provincial funding of postsecondary education under the Established Programs Financing (EPF) arrangements introduced in 1977. Since 1977, federal transfers to the provinces for financing postsecondary education have increased in line with the growth rate of nominal gross national product, rather than in line with operating costs. Because the federal transfers were unconditional grants, the provinces were not obliged to spend the postsecondary transfers on higher education. Consequently, the block grant under EPF has led to provincial spending restraint on postsecondary education.
\end{abstract}

\section{RÉSUMÉ}

Cette étude examine le système du financement d'enseignement postsecondaire sous le financement des programmes établis (FPE) autorisés par la loi de 1977 sur les accords fiscaux entre le gouvernement fédéral et les provinces. Depuis 1977 , les transferts fédéraux aux provinces, au titre du financement de l'enseignement postsecondaire, ont augmenté en proportion avec le taux de croissance du produit national brut en terme réel plutôt qu' en proportion de la croissance des frais de fonctionnement des institutions postsecondaires. Parce que les transferts fédéraux étaient inconditionnels, les provinces étaient nullement dans l'obligation d'utiliser ces fonds pour financer l'éducation postsecondaire. Il en résulte que le système de financement inconditionnel a, en somme, ralenti les dépenses des provinces dans le domaine de l'éducation postsecondaire.

\section{INTRODUCTION}

The financial plight of Canada's postsecondary institutions has recently drawn considerable public attention through the news media. Much of the public concern

* I would like to thank Fletcher Baragar for his helpful comments on an earlier draft. I am also grateful to two anonymous referees for helpful comments and suggestions. However, I alone accept responsibility for any errors which may remain.

** Faculty of Administration, University of Regina 
is focused on the provincial underfunding of postsecondary education. ${ }^{1}$ Since Canadian universities and colleges are heavily dependent upon the provincial governments for financial support, the provincial spending cuts on postsecondary education have resulted in substantial cutbacks in higher education in recent years. In response to the inadequate funding from the provincial governments, most postsecondary institutions have implemented many drastic cost-saving measures to cope with the financial squeeze. For example, enrolment quotas are imposed, salaries for academic staffs are frozen, library hours are reduced, and courses are cancelled. As a result of these cutbacks, college buildings are decaying, equipment is broken down and obsolete, library books are incomplete, and classes are overcrowded. While students are faced with increased tuition fees and enrolment quotas, academic staffs are confronted with insecure academic careers and shrinking research funds. Indeed, the financial situation of the universities and colleges has now reached a critical stage where further cutbacks could place the quality of higher education in jeopardy.

The central questions are: how much did the provincial governments actually spend on postsecondary education? Did the provincial governments reduce their spending on postsecondary education? To what extent was the provincial spending on postsecondary education influenced by federal transfers? In order to answer these questions, it is necessary to examine the provincial expenditures on postsecondary education in relation to federal transfers. Prior to 1977 , the federal funding of postsecondary education was financed by a conditional matching grant based on the province's operating costs. Since 1977, the federal government has replaced the matching grant with a lump-sum block grant covering the three major program areas: hospital insurance, medicare and postsecondary education. The focus of this study is concerned with the provincial spending on postsecondary education under the Established Programs Financing (EPF) arrangements introduced in 1977.

In spite of the growing amount of literature on federal transfers to postsecondary education under the EPF arrangement (Carter, 1982; Leslie, 1980; Wu, 1985), comparatively little attention has been devoted to the provincial expenditures on postsecondary education. This study analyzes the pattern of provincial expenditures on postsecondary education between 1977 and 1983. In particular, an attempt will be made to evaluate the budgetary impact of EPF on provincial expenditures with respect to postsecondary education. It is hoped that this study will provide some useful insights into the underlying cause of provincial underfunding of higher education.

\section{AN OVERVIEW OF THE ESTABLISHED PROGRAMS FINANCING}

Since the EPF arrangement has been discussed elsewhere (Boadway, 1980; Carter, 1982; Leslie, 1980; Wu, 1985), only a general overview of the federal funding arrangement for financing postsecondary education will be presented here. In 1977, the federal government and the provinces agreed to the Established 
Programs Financing (EPF) arrangement which changed the formula for financing hospital insurance, medicare and postsecondary education from three separate cost-sharing grants to a single block grant. Under the block funding arrangement, 32.1 percent of the federal transfers were allocated to postsecondary education, 50.5 percent to hospital insurance and 17.4 percent to medicare expenditures. These percentages which were based on the program cost ratios of the three established programs in the base year 1975-76, represented only a notional allocation of the EPF transfers. Since the federal transfers were unconditional in nature, the provinces were not obliged to spend the designated 32.1 percent of the EPF transfers on postsecondary education.

The calculation of the federal transfer was fairly complex. The federal transfer consisted of two components: tax transfers and cash transfers. The tax transfer consisted of a federal reduction of 1 percent of the corporation income tax and 13.5 percent of the personal income tax. This allowed each province to receive a "tax room" of an equivalent amount. The cash transfer included three components: the basic cash contribution, the transitional adjustment payment, and the levelling adjustment payment. The basic cash contribution consisted of 50 percent of the national average per capita federal contributions to the three established programs in the base year $1975-76$ plus $\$ 7.63$ per capita. ${ }^{2}$ The transitional adjustment payment was made up of the difference between the basic cash contribution and the tax transfer in order to ensure that no province would lose any revenues by accepting part of the federal contribution in the form of tax points rather than cash payment. The levelling adjustment payment was designed to remove the interprovincial disparities in the per capita federal contributions.

The main characteristic of the new funding formula was that there were no strings attached to the federal transfers designated for postsecondary education. Since the provinces were not compelled to spend the designated proportions on individual programs, they could spend less than 32.1 percent of the EPF transfers on postsecondary education if they preferred. The implication of such a fiscal arrangement is that the EPF transfer provided virtually no incentive to the provinces to undertake expenditures on postsecondary education.

In 1982, the EPF funding formula was simplified to a great extent by the elimination of the three different cash components. Hence, the total federal contributions to the three established programs were equal to the national average per capita federal contribution in 1975-76 rather than 50 percent under the 1977-82 arrangement (Perry, 1983). In 1983, the federal government extended the "six and five programs" to postsecondary transfers by limiting increases in the per capita federal contribution for postsecondary education to six percent in 1983-84, and to five percent in 1984-85.

\section{TRENDS IN PROVINCIAL FUNDING}

In order to examine the budgetary impact of EPF transfer on provincial spending, it is necessary to analyze the pattern of provincial expenditures with respect to 
postsecondary education. This section presents the provincial funding trends in postsecondary education between 1977 and 1983.

Table 1 shows the provincial spending on postsecondary education under the EPF arrangements from 1977-78 to 1982-83. Total provincial expenditures on postsecondary education increased from $\$ 3.4$ billion in $1977-78$ to $\$ 5.7$ billion in 1982-83, which represented an annual growth rate of 10.9 percent. Over the six year period from 1977-78 to 1982-83, the provinces spent a total of $\$ 26.95$ billion.

Table 2 presents the real provincial spending on postsecondary education from 1977-78 to 1982-83. In real terms, total expenditures in all provinces combined were constant at $\$ 2$ billion since 1977-78. This suggests that the provincial spending on postsecondary education had been frozen since the inception of EPF. Thus, the annual national growth rate was only 1.04 percent from 1977 to 1983 . It is interesting to note that in 1982-83 five provinces (Newfoundland, Prince Edward Island, Nova Scotia, Ontario and Manitoba) had real provincial spending well below the 1977-78 level. ${ }^{3}$ Undoubtedly, some of these provinces experienced financial constraints during the economic downturn and therefore had to cope with cutbacks in most programs, including postsecondary education. Nevertheless, it is more likely that to a considerable extent the federal block grants had induced the provinces to curtail their postsecondary education expenditures. Over the period $1977-83$, the provinces spent a total of $\$ 12.2$ billion in $1971-72$ constant dollars on postsecondary education.

Table 3 shows the real per capita provincial spending on postsecondary education from 1977-78 to 1982-83. As can be seen from this Table, there were large disparities in per capita spending among the provinces. In 1978-79, for example, Alberta spent $\$ 107.53$ per capita on postsecondary education while Saskatchewan spent only $\$ 65.32$ per capita. It should be emphasized that the per capita federal grant was equalized in all provinces in 1982-83 when the EPF arrangement was renewed $(\mathrm{Wu}, 1985)$. However, the uniform per capita federal grant did not induce the provinces to equalize their spending on postsecondary education. For example, in 1982-83 the per capita provincial expenditure was $\$ 128.93$ in Alberta compared with \$63.33 in Prince Edward Island. This suggests that the EPF arrangements had equalized the per capita federal grant rather than the per capita provincial spending. As well, in 1982-83 six provinces had per capita provincial spending lower than that in 1977-78. This implies that most provinces had actually cut back their spending in per capita terms since the inception of EPF. Conceivably, the overall provincial budgetary restraint could have contributed partly to the decline in provincial postsecondary education expenditures.

The real provincial spending per full-time equivalent student is shown in Table $4 .^{4}$ In order to capture the surge in postsecondary part-time enrolment, the full-time equivalent student is used instead of full-time student in this Table. As can be seen from Table 4 , there were large disparities in the real provincial spending per student among the provinces. While the provincial spending per student was $\$ 4,805$ in Alberta in $1982-83$, it was only $\$ 2,109$ in Ontario. The figures also reveal that the real provincial spending per student declined steadily in 
Provincial Funding of Postsecondary Education Under

TABLE

PROVINCIAL SPENDING ON POST SECONDARY EDUCATION, 1977-83

(in current thousands of dollars)

\begin{tabular}{|c|c|c|c|c|c|c|}
\hline & $1977-78$ & $1978-79$ & $1979-80$ & $1980-81$ & $1981-82$ & $1982-83$ \\
\hline $\begin{array}{l}\text { Nfld. } \\
\text { P.E.I } \\
\text { N.S. } \\
\text { N.B. } \\
\text { Que. } \\
\text { Ont. } \\
\text { Man. } \\
\text { Sask. } \\
\text { Alta. } \\
\text { B.C. }\end{array}$ & $\begin{array}{r}70,686 \\
16,562 \\
100,801 \\
80,431 \\
1,089,413 \\
1,175,536 \\
138,137 \\
115,226 \\
340,000 \\
322,523\end{array}$ & $\begin{array}{r}74,404 \\
19,154 \\
110,033 \\
87,547 \\
1,197,121 \\
1,264,943 \\
129,079 \\
113,912 \\
399,672 \\
373,654\end{array}$ & $\begin{array}{r}85,750 \\
19,618 \\
117,335 \\
95,923 \\
1,311,591 \\
1,323,990 \\
141,029 \\
134,283 \\
466,021 \\
456,773\end{array}$ & $\begin{array}{r}97,415 \\
21,432 \\
128,575 \\
109,155 \\
1,471,833 \\
1,403,802 \\
150,010 \\
119,688 \\
533,818 \\
514,760\end{array}$ & $\begin{array}{r}97,914 \\
18,643 \\
147,583 \\
118,897 \\
1,687,797 \\
1,523,098 \\
174,240 \\
162,335 \\
660,527 \\
641,607\end{array}$ & $\begin{array}{r}111,804 \\
21,449 \\
157,505 \\
143,877 \\
1,810,478 \\
1,724,002 \\
198,081 \\
184,160 \\
827,397 \\
617,314\end{array}$ \\
\hline Can. & $3,449,315$ & $3,769,519$ & $4,152,313$ & $4,550,488$ & $5,232,642$ & $5,796,067$ \\
\hline
\end{tabular}

Source: Statistics Canada, Provincial Government Finance: Revenue and Expenditure.

TABLE 2

REAL PROVINCIAL SPENDING ON POST SECONDARY EDUCATION, $1977-83$

( in constant thousands of dollars, 1971-72=100)

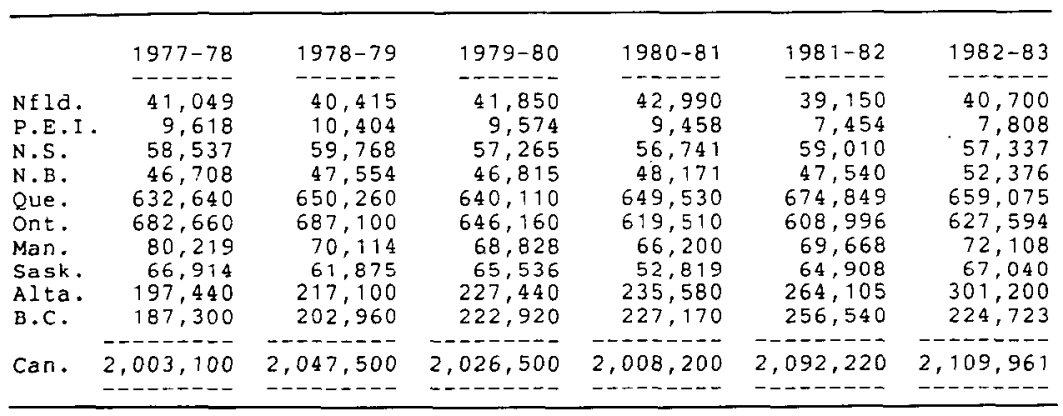

Note: a. These figures are adjusted by the GNE deflator.

Sources: Computed from data in Table 1 and Statistics Canada, National Income and Expenditure Account.

most provinces since 1978-79. As a consequence, the per student provincial spending in 1982-83 was much lower than that in 1977-78 in most provinces. Of particular interest is that there were substantial spending cuts in some provinces. This was especially the case in Newfoundland, Prince Edward Island and Ontario, where real spending per student in $1982-83$ was 24 percent below the $1977-78$ level. While the provincial fiscal restraints might have led to a reduction in provincial funding, the EPF arrangement had undoubtedly induced. some provinces to cut back their expenditures significantly on postsecondary education.

In order to ascertain whether the change of funding arrangement in 1977 affected the provincial funding of postsecondary education, it is necessary to compare the 
TABLE 3

REAL PER CAPITA PROVINCIAL SPENDING ON POSTSECONDARY EDUCATION, $1977-83$ a

( in constant dollars, 1971-72=100)

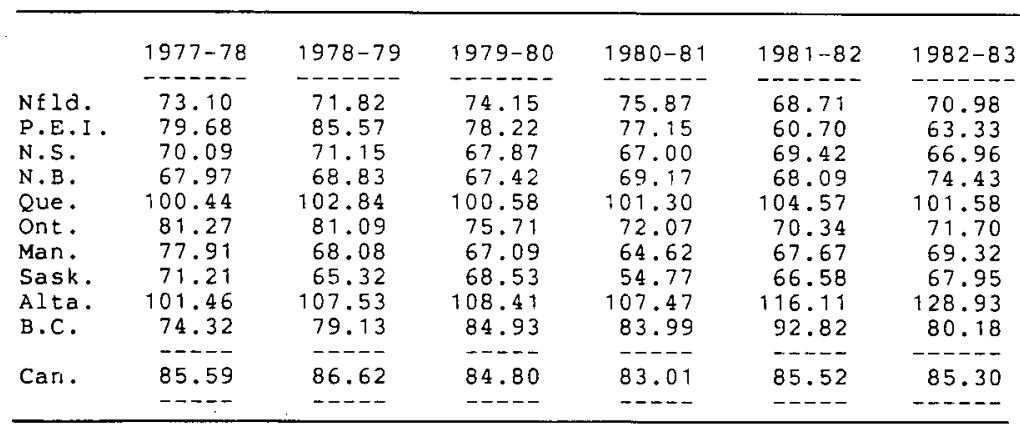

Note: a. Provincial expenditures are adjusted by the GNE deflator.

Sources: Computed from Table 2 and Statistics Canada,

Quarterly Estimates of Population for Canada and the provinces.

TABLE 4

REAL PROVINCIAL SPENDING PER FULL-TIME EQUIVALENT STUDENT a

( in constant dollars, 1971-72=100) b

\begin{tabular}{|c|c|c|c|c|c|c|}
\hline & $1977-78$ & $1978-79$ & $1979-80$ & $1980-81$ & $1981-82$ & $1982-83$ \\
\hline $\begin{array}{l}\text { Nfld. } \\
\text { P.E.I. } \\
\text { N.S. } \\
\text { N.B. } \\
\text { Que. } \\
\text { Ont. } \\
\text { Man. } \\
\text { Sask. } \\
\text { Alta. } \\
\text { B.C. }\end{array}$ & $\begin{array}{l}4,139 \\
3,742 \\
2,508 \\
3,299 \\
2,622 \\
2,769 \\
3,215 \\
3,350 \\
3,788 \\
3,631\end{array}$ & $\begin{array}{l}4,398 \\
4,278 \\
2,609 \\
3,410 \\
2,614 \\
2,798 \\
2,944 \\
3,184 \\
4,195 \\
3,905\end{array}$ & $\begin{array}{l}4,275 \\
4,066 \\
2,526 \\
3,319 \\
2,545 \\
2,555 \\
2,989 \\
3,390 \\
4,387 \\
4,245\end{array}$ & $\begin{array}{l}4,181 \\
3,971 \\
2,442 \\
3,339 \\
2,516 \\
2,333 \\
2,777 \\
2,682 \\
4,415 \\
4,175\end{array}$ & $\begin{array}{l}3,456 \\
2,930 \\
2,436 \\
3,058 \\
2,530 \\
2,184 \\
2,730 \\
3,065 \\
4,662 \\
4,547\end{array}$ & $\begin{array}{l}3,146 \\
2,868 \\
2,193 \\
3,107 \\
2,352 \\
2,109 \\
2,574 \\
2,903 \\
4,805 \\
3,718\end{array}$ \\
\hline---- & $\ldots$ & $\ldots--$ & ---- & $\ldots$ & ----- & $-\ldots$ \\
\hline Can. & 2,918 & 2,968 & 2,894 & 2,769 & 2,756 & 2,602 \\
\hline
\end{tabular}

Notes: a. These transfers are calculated on a full-time equivalent basis. That is, full-time university and college students plus a full-time equivalent of part-time university students, based on a conversion factor of 3 to 1 .

b. Provincial expenditures are adjusted by the GNE deflator. Sources: Computed from data in Table 2 and Statistics Canada, Education in Canada.

pattern of provincial postsecondary education expenditures before and after the introduction of EPF. Table 5 presents an index of provincial postsecondary education expenditures per full-time equivalent student from 1970-71 to 1982-83. Prior to 1977, the provinces received the 50:50 cost-sharing grant for financing postsecondary education. As a result of such a funding arrangement, provincial spending on postsecondary education increased steadily from 1970-71 to 
TABLE 5

INDEXES OF PROVINCIAL POSTSECONDARY EDUCATION EXPENDITURE

PER FULL TIME EQUIVALENT STUDENT

$(1970-71=100)$

\begin{tabular}{|c|c|c|c|c|c|c|c|c|c|c|}
\hline Provinces & $\underline{1970-71}$ & $1972-73$ & $1974-75$ & $1976-77$ & $1977-78$ & $1978-79$ & $1979-80$ & $1980-81$ & $1981-82$ & 1982-83 \\
\hline $\begin{array}{l}\text { Nfld. } \\
\text { P.E.I. } \\
\text { N.S. } \\
\text { N.B. } \\
\text { Que. } \\
\text { Ont. } \\
\text { Man. } \\
\text { Sask. } \\
\text { Alta. } \\
\text { B.C. }\end{array}$ & $\begin{array}{l}100.0 \\
100.0 \\
100.0 \\
100.0 \\
100.0 \\
100.0 \\
100.0 \\
100.0 \\
100.0 \\
100.0\end{array}$ & $\begin{array}{l}130.7 \\
109.6 \\
121.3 \\
115.8 \\
134.9 \\
104.6 \\
138.8 \\
115.0 \\
103.4 \\
116.4\end{array}$ & $\begin{array}{r}148.3 \\
90.1 \\
126.5 \\
121.5 \\
133.6 \\
92.8 \\
126.9 \\
117.6 \\
87.9 \\
107.9\end{array}$ & $\begin{array}{r}156.5 \\
118.3 \\
116.5 \\
161.3 \\
149.7 \\
93.8 \\
133.4 \\
131.4 \\
85.9 \\
111.2\end{array}$ & $\begin{array}{r}147.3 \\
146.9 \\
111.8 \\
173.9 \\
167.0 \\
98.6 \\
136.1 \\
124.0 \\
90.7 \\
122.0\end{array}$ & $\begin{array}{r}156.6 \\
167.9 \\
116.3 \\
179.8 \\
160.5 \\
99.6 \\
124.6 \\
117.9 \\
100.4 \\
131.2\end{array}$ & $\begin{array}{r}152.2 \\
159.6 \\
112.6 \\
175.0 \\
156.2 \\
91.0 \\
126.5 \\
125.5 \\
105.0 \\
142.6\end{array}$ & $\begin{array}{r}148.8 \\
155.8 \\
108.9 \\
176.0 \\
154.5 \\
83.1 \\
117.5 \\
99.3 \\
105.7 \\
140.3\end{array}$ & $\begin{array}{r}123.0 \\
115.0 \\
108.6 \\
161.2 \\
155.3 \\
77.8 \\
115.5 \\
113.5 \\
111.6 \\
152.8\end{array}$ & $\begin{array}{r}112.0 \\
112.6 \\
97.8 \\
163.8 \\
144.4 \\
75.1 \\
108.9 \\
107.5 \\
115.0 \\
124.9\end{array}$ \\
\hline Canada & 100.0 & 113.5 & 105.6 & 110.7 & 116.3 & 118.2 & 115.3 & 110.3 & 109.8 & 103.7 \\
\hline
\end{tabular}

Source: Computed from data in Statistics Canada, Provincial Government Finance: Revenue and Expenditure and Statistics Canada, Education in Canada. 
1976-77. ${ }^{5}$ However, after the funding arrangement was switched from costsharing to EPF in 1977, a somewhat different funding pattern emerged as illustrated in Table 5. Under the EPF arrangement, provincial postsecondary education expenditures declined gradually from 1978-79 onwards. Given the downward trend of provincial funding in the EPF period, it is clear that the provinces had reduced their expenditures on postsecondary education in response to the new funding arrangement.

From the above discussion, it is apparent that provincial postsecondary education expenditures (in both per capita and per student terms) declined steadily since the introduction of EPF. More importantly, the upward funding trend was abruptly reversed after the inception of the EPF arrangement. This reflects the fact that the block grant under EPF had caused a reduction in provincial spending effort in the area of higher education.

It should be noted that the above funding trends are analyzed only up to 1982-83 because expenditure data are not available for 1983-84 and 1984-85. Given the expenditure pattern presented in this section, it is reasonable to expect that the provincial policy of expenditure restraint would continue both in 1983-84 and in 1984-85. Perhaps the provincial spending cuts on postsecondary education would be even more striking if additional data were available for these two years.

\section{IMPLICATIONS}

On the basis of the preceding analysis, it is conceivable that there is a direct link between the EPF transfers and the provincial expenditures with respect to postsecondary education. First, unlike the previous cost-sharing scheme, the provinces were given more flexibility in the allocation of their own funds with respect to postsecondary education under the block funding arrangement. Since the block grant was unconditional, the provinces could spend the deemed EPF money on other programs if they preferred. In light of the growing budgetary deficits, the provinces were likely to divert the federal transfers designated for postsecondary education to other social programs. Under these circumstances, the provinces were tempted to cut back their expenditures on higher education because the EPF transfers were determined independently of provincial outlays.

Second, under the EPF, there were large disparities in per capita provincial spending among the provinces. On a per capita basis, the richer provinces (e.g. Alberta and Quebec) tended to undertake more expenditures on postsecondary education than the poorer provinces (e.g. Prince Edward Island and Nova Scotia). ${ }^{6}$ More specifically, the EPF transfer had induced the richer provinces to contribute more funds to finance postsecondary education compared with the poorer provinces. As mentioned earlier, the funding formula enabled the provinces to receive equal per capita grants. The equality in per capita grants, however, did not lead to corresponding equality in the per capita provincial spending among the provinces. Given the large variations in provincial spending, it is questionable that interprovincial equity has been achieved under EPF. 
Finally, most provinces took advantage of the EPF funding arrangement and reduced their spending significantly on higher education. This is reflected by the fact that there had been gradual reductions in the provincial expenditures on postsecondary education since the introduction of EPF. Although the recession could have restrained provincial postsecondary education expenditures, it is reasonable to assume that the EPF transfer was largely responsible for the decline in provincial spending on postsecondary education. ${ }^{7}$ This is because the unconditional federal transfers had in effect reduced the provincial spending incentive on postsecondary education. ${ }^{8}$ As a result of the unconditional nature of postsecondary education transfers coupled with overall budgetary restraints, universities and colleges were compelled to undertake substantial cutbacks to cope with the financial pinch.

\section{CONCLUSIONS}

In view of the funding trends presented in this study, it is evident that the provincial spending restraint had taken place in the area of postsecondary education since the introduction of EPF. Over the years, the block funding arrangement generously allowed the provinces to curtail their level of support for higher education. These results are not surprising because the observed pattern of provincial expenditures on postsecondary education is consistent with the predicted fiscal response that the stimulative effect of an unconditional grant on provincial expenditure is rather minimal.

Under the EPF arrangement, the provincial governments received the federal transfer payments for financing postsecondary education in the form of an unconditional grant. In essence, the unconditional grant gave the provinces complete freedom in deciding their expenditure levels with respect to higher education. Since the provinces were not obliged to spend the federal transfers on postsecondary education, they were virtually free to spend the federal grants on any programs. Under these circumstances, there was a strong incentive for the provinces to divert the federal funds to some other programs that were more preferred by the provinces. ${ }^{9}$ Such a flexible funding formula inevitably enabled the provinces to cut back substantially their spending on postsecondary education.

From the provincial perspective, the EPF funding scheme was an ideal form of transfer mechanism because it allowed the provinces to structure their own spending priorities without any loss of federal contributions. In contrast, the EPF arrangement was a complete failure from the federal government's standpoint since it did not encourage the provinces to maintain their relative level of financial support for postsecondary education, let alone to increase it. It can be argued that the EPF transfer was undesirable in that it was ineffective in maintaining a national standard in the area of postsecondary education. In order to prevent provincial use of postsecondary education grants for other purposes, a conditional matching grant should be used because it would compel the provinces to spend the designated federal funds only on postsecondary education. Certainly, whether such a funding scheme is politically feasible is another matter. 


\section{NOTES}

1. Throughout this paper, the term "postsecondary education" is used interchangeably with the term "higher education".

2. In subsequent years, the cash contribution was escalated through time by the growth of the provincial population and the economy. The growth of the economy is based on a three-year moving average of the annual growth rate of nominal per capita GNP.

3. As well, these five provinces contributed a lower proportion of their provincial budgets to higher education in 1982-83 than they did in 1977-78.

4. Part-time enrolment is converted to full-time equivalent enrolment by using a factor of 3 to 1 (i.e. 3 part-time students to 1 full-time student).

5. Notwithstanding these increases, there was a slight decline in provincial postsecondary education expenditures in 1972-73 as the actual federal transfers were reduced by the imposition of a 15 percent growth ceiling.

6. The categorization of the provinces is based on the province's per capita personal income. The province whose per capita personal income above the national average is considered to be a rich province whereas the province whose per capita personal income below the national average is considered to be a poor province.

7. In order to contain the growing budgetary deficits, the provinces had to cut back their expenditures on most public services. Since postsecondary education was traditionally not a top spending priority in the provincial budgets, the provinces were unlikely to treat postsecondary education more generously than health services and other public programs in the wake of overall budgetary cutbacks.

8. According to the economic theory of grants, an unconditional grant involves an income effect whereas a conditional matching grant involves a price effect (a combination of the substitution and the income effects). It is expected that a conditional matching grant is more stimulative on provincial expenditure than an unconditional grant because the former has a price effect whereas the latter has only an income effect.

9. As well, hospital insurance, medicare service, and social welfare programs are politically more visible to the public.

\section{REFERENCES}

Boadway, R.W. Intergovernmental Transfers in Canada. Toronto: Canadian Tax Foundation, 1980.

Brown, M.C. Established Program Financing: Evolution or Regression in Canadian Fiscal Federalism? Research Monograph No. 38, Canberra: The Australian National University, 1984.

Canadian Association of University Teachers. The Funding of Canadian Universities. Mimeographed, 1981.

Canadian Association of University Teachers. Established Programme Funding. Newsletter, 1981.

Carter, G.E. Financing Health and Postsecondary Education: A New and Complex Fiscal Arrangement. Canadian Tax Journal, 1977, 25(5), 534-550.

Carter, G.E. The Federal Impact on Financing Higher Education in Canada. Occasional Paper No. 25, Canberra: The Australian National University, 1982.

Courchene, T.J. Refinancing the Canadian Federation: A Survey of the 1977 Fiscal Arrangements Act. Montreal: C. D. Howe Research Institute, 1979.

Department of Finance. Fiscal Arrangements in the Eighties - Proposals of the Government of Canada. Ottawa, Queen's Printer, November 1981.

Department of Finance. Federal-Provincial Fiscal Arrangements in the Eighties. A Submission to the Parliamentary Task Force on the Federal-Provincial Fiscal Arrangements by Allan J. MacEachen, Ottawa: Queen's Printer, April 1981. 
Provincial Funding of Postsecondary Education Under

49 the Established Programs Financing

Economic Council of Canada. Financing Confederation: Today and Tomorrow. Ottawa: Supply and Services Canada, 1982.

Federal-Provincial Relations Office. Federal-Provincial Programs and Activities. Ottawa, Queen's Printer, Various Issues.

Kapsalis, Constantine. Block-Funding and Provincial Spending. Canadian Tax Journal, 1982, 30(2), 219-227.

Leslie, P.M. Canadian Universities 1980 and Beyond. Ottawa: Association of Universities and Colleges of Canada, 1980.

Nowlan, D.M. \& Bellaire, R. (ed.). Financing Canadian Universities: For Whom and By Whom? Toronto: OISE Press, 1981.

Parliamentary Task Force on Federal-Provincial Fiscal Arrangements. Fiscal Federalism in Canada. Ottawa: Queen's Printer, 1981.

Perry, D.B. Fiscal Figures. Canadian Tax Journal, 1981, 29(2), 246-251.

Perry, D.B. The Federal-Provincial Fiscal Arrangements for 1982-87. Canadian Tax Journal, 1983, 31(1), 30-47.

Social Science Federation of Canada. Federal-Provincial Funding of Research and Universities: Proposals from the Social Science Federation of Canada of Issues of Established Programs Financing. Ottawa, 1982.

Statistics Canada. Education in Canada. (Cat. no. 81-229), Ottawa, Various Issues.

Statistics Canada. Financial Statistics of Education. (Cat. no. 81-208), Ottawa, Various Issues.

Statistics Canada. National Income and Expenditure Accounts. (Cat. no. 13-533), Ottawa, Various Issues.

Statistics Canada. Provincial Government Finance: Revenue and Expenditure. (Cat. no. 68-207), Ottawa, Various Issues.

Statistics Canada. Quarterly Estimates of Population for Canada and the Provinces. (Cat. no. 91-001), Ottawa, Various Issues.

Statistics Canada. University Financial Statistics. (Cat. no. 81-212), Ottawa, Various Issues.

Wu, T.Y.S. Federal Contributions to Postsecondary Education Under the Established Programs Financing: Trends and Implications. The Canadian Journal of Higher Education, 1985, 15(1), 11-23. 